\title{
Integrated Transportation
}

\author{
John W. Wheeler, Executive Assistant, Burlington Lines \\ Chicago, Illinois
}

Motor trucks in themselves are not transportation, nor are railroads, nor airplanes, nor barges, nor pipelines; but, when bunched together and integrated, they become transportation. I saw a great example of integrated transportation in what is now West Germany. They used the type of transportation which was the most economical for the people with all factors considered. Their highways are excellent. Their trucks are likewise. I never saw better railroads. Their barges are everywhere, although much smaller than ours; and we know they are building up a great airline. We know further that West Germany has progressed more rapidly in the last ten years than any country in the world; their ideas of transportation, in my opinion, are very sound.

We have not developed in this country enough experts in transportation. It is true we have automobile experts, railroad experts, barge and air traffic experts, and pipeline experts; but tell me one man whom we can all point our finger at an an expert in transportation-integrated transportation-who looks at it objectively for the good of our nation. It is true that we have many chairs of transportation in many universities. However, the man occupying that chair, be he the most eminent professor, probably has not switched a freight car, driven a truck, cast the lines off a barge, flown a plane, nor turned the valves on a pipeline. We need to develop a few men-perhaps not a few, perhaps many men-who are proficient in all the branches of transportation, so that our nation can take advantage of all of the forms and get the best out of them, and use that form which is the most satisfactory and economical to the public. I would like to see a good smart boy, preferably a graduate in civil engineering, do a three-year hitch with a state highway or a contractor, a second three years with the railroads, a third three years with the barges, a fourth three years with the airplanes, and maybe only a year with the pipelines because they are generally simple, and then see if we have not developed a transportation expert. I know of no man today who fills those specifications, and I think we need him badly.

I will mention one form of integrated transportation that is enjoying growing success, and that is what we call Piggy-back. I was not 
the first one who thought of putting trailers on flat-cars. In fact, that was tried by a railroad and a trucking company when I was a member of the Indiana Highway Commission, but for some reason it died. It was tried again on a short haul between Chicago and Milwaukee, and that died as we would expect because of the short haul. I was, however, one of a group who resurrected Piggy-back immediately after World War II, and it is still growing.

Here we are using the best in transportation. There is no vehicle as flexible as the semi-trailer; we take him to the source of shipment, load him, put him on a flat-car, unload him at the end of a long haul, take him to his destination, and we have saved two handlings of the goods and moved the goods much cheaper over the long haul. This will continue to grow. I do not believe the different forms of transportation should quarrel with one another. I am afraid there has been too much of that. The railroads and the truckers apparently are getting along fine on this Piggy-back deal. This is just one instance of what I mean by integrated transportation-that form which gives the public transportation at the lowest cost, let the chips fall where they may.

So, it is my plea to the Forty-Fifth Road School, to the Joint Highway Research Board, to the School of Engineering of Purdue, and to the Indiana Highway Commission, which I had the good fortune to serve, to think about bringing forward in some manner the training of a transportation expert. May I repeat "Integrated Transportation." As a railroad man, I will say that we will take our chances.

The second part of my paper is entitled, "What The Hell Is The Matter With Us?" It was my fortune, good or bad, to take part in two wars-and the second one for a man over fifty was a dilly. I lived under the V-1 and the V-2, and all of the other bombs they had, and really got into the war at its worst. Today we read from the so-called experts that we are behind the Soviet in our missile production and the Soviet is about to destroy us. On the next day, a man of equal intelligence tells us that we are not behind the Soviet, that the Soviet cannot destroy us, and that if the chips are down we can destroy the Soviet. And that goes on ad infinitum. Well, I'll tell you, I am no more afraid of an atomic war, which would probably last two or three days, than I am of a flight of carrier pigeons. But, I'll tell you what I am afraid of; and I hope I can scare you. We are going into an economic war-in reality we are in an economic war-the like of which we have never seen. I am not too certain who will win that war.

When I left the Ruhr Valley in Germany at the end of the war, it was nothing but a shambles; I need not tell you that they are now 
producing five times as much steel as they did before the war. They are a most able people; and, from by observation, take advantage of integrated transportation, namely, that form which is the best and cheapest for the people.

The Cleveland Chamber of Commerce called Roger Blough, Chairman of U. S. Steel, to speak to them during the so-called recession about nine months ago, and asked him to tell what was the matter. $\mathrm{Mr}$. Blough said, "I will tell you what is the matter, but I will not use the Cleveland Chamber of Commerce for a sounding board as to my ideas for the cure." He then continued and said, "Gentlemen, I can buy barbed wire in Dusseldorf on the Ruhr and sell it to you on the loading platform at Cleveland $\$ 40$ a ton cheaper than I can sell you our barbed wire made in America." He then told them that they were as smart as he was in figuring out what to do.

Each week I drive to my office in Chicago and I see more and more foreign cars, cute little jobs that can be parked and can be driven into your garage. My wife and I remark about them, and I tell her that the number of cars we see on the expressway and on the outer drive does not mean too much, but the number of these foreign cars going to Rio de Janeiro, Buenos Aires, Singapore, New Delhi, etc., is going to hurt because up to a few years ago we had that market and American cars went in there. Japan has recently shipped its first shipload of automobiles to the west coast of the United States. The Japanese are rugged competitors whom we must not destroy since they are one of our military allies. It is my understanding, and I cannot prove this, that the Japanese only bought one Caterpillar tractor. They then took it apart, and they made duplicate parts with enough changes to prevent infringement of international patents; I fear we are now shipping very few Caterpillars to Japan. The Chinese have just started to build motor trucks. You know as well as I do the impetus that has been given to foreign-made motor vehicles all over the world. I am not capable of discussing the other products which they are selling all over the world, but I suspect they are many.

In a recent issue of the $W$ all Street Journal there was a long article on the importation of machine tools by companies in the United States. Apparently we are buying machine tools in many of the foreign countries, although we can make as good machine tools as anybody. Many American firms are buying into foreign manufacturing plants and making their product there and shipping it over here. Clearly that is not the answer. The automobile worker is not helped a bit by General Motors selling an Opel, which is the German Chevy. It sells for less in America than our car, but no American workman has gotten a 
cent from it. The paycheck when to a German. So, the automobile companies that are merely bringing over their foreign cars are not helping us a bit if we wish to keep our people employed, which becomes a bigger problem each day with automation.

During my service in India, I spent a great deal of time in Calcutta, and nearby was the Tato Steel Works and the India Steel Company. That was fifteen years ago, and they have been enlarged greatly with foreign capital (I believe ours, perhaps some from West Germany, perhaps some from the Soviet) until those two great mills are probably gigantic. India has great quantities of coal and iron ore. Those of us who live in the shadow of the Gary Works would feel bad to see I-beams or other structural shapes shipped into Gary from India.

For the last 50 years, in my opinion, we have become a nation of smart alecks who thought that we could take hogs apart faster in Chicago, and put automobiles together faster in Detroit, than anyone in the world. And for a time that was true. It was true so long that we built up a false idea of our ability. I think, in Hoosier terms, the chickens are about to come home to roost.

For many years we thought the other nations were people, but clods. We saw the picture of a Russian peasant with a hoe, the French people with a flail, and we thought it was the whole picture. I believe I can be backed up in saying that when Purdue University was organized under the Morrill Land Grant Act, John Purdue gave the land and some money, and, because under the land grant act the new school had to teach agriculture and the mechanic arts-a committee was sent to Moscow, and Purdue was set up as a copy of the University of Moscow. The University of Moscow was probably a hundred years old when Purdue was born. True they do not operate as we like to operate, but they have sent a certain number of smart Russians through their technical schools to the extent that we should not have been too surprised that they put up the first Sputnik. The same goes for all of the European countries. If you will read your histories, many of the greatest scientists accomplished their work before we had an engineering school in America; we have yet to find error in the works of Newton or Galileo.

So, in my opinion, we are in for an economic war; and before it is over we will tighten our belts, and you may interpret that any way you choose.

Because we are a school of ag and engineering, let us talk for a moment about the school south of State Street, of which there is no better. Let us see if our economy is becoming, in the vernacular, 
fouled up. Let us take a hypothetical boy who was raised on a farm and graduated in ag at Purdue but has no money at graduation. There is no sense in trying to farm less than 240 acres, so, we will let him borrow the money to buy a good 240 acres. To show you that my reasoning is fair I will say that he could buy it for $\$ 200$ an acre, (which is not so) but assuming $\$ 200$ an acre he has now borrowed $\$+8,000$. He must then go to the implement dealers and borrow at least $\$ 25,000$ more for tractors, combines, bailers, etc., and now he is in debt $\$ 73,000$. Let us think a minute about his chances of paying that off. I have tried to get the statistics on what the average Indiana farmer, makes per hour for his work over the year. I am not certain although I have had good help but in each case I have been told to use the figures cautiously. I have just such a farm as I described, and a good Purdue ag graduate farming it. It is my opinion, that this farmer does well to have 90 cents an hour for his year's work, although the man who works assembling his tractor probably receives close to $\$ 3$ an hour. Gentlemen, I tell you it is not going to work. We talk about our skilled mechanics in America and our production lines in Detroit; but, go up there and watch the so-called skilled mechanic stand as the material passes him on a belt and stick a bolt in a hole as it goes by while a man on the other side puts a nut on it. If that is a skilled mechanic, I'm a Chinaman with a haircut.

When will agriculture become more profitable for the farmer? Let us look at farm surplus. We pay the farmer for not planting as many acres, and then teach him how with fertilizers and hybrid seed to raise twice as much as he raised before and for which there is no market. After the farmer picks the corn and puts it in cribs, he shells it and it is hauled to one of those villages of wrinkled ten corn cribs which haunt the scenery of Indiana and other cornbelt states, where the corn is placed and allowed to spoil beyond value for human consumption. It is then taken out of the wrinkled tin igloo and shipped by rail or truck to tidewater and placed in the hold of the great fleet of Liberty ships. After it is further spoiled in the hold of the Liberty ship, it is taken out to sea and dumped. At this same time, we loan cash money to foreign countries who take our money and buy grain from iron curtain countries, and the dog continues to chase his tail.

In closing may I say to you that I do not fear the atomic bomb because both sides have it, as both had gas in World War II and did not use it; but, I say to you, look out for an economic war and be ready to pull up your belt. 